\title{
Cadmium exposure in the population: from health risks to strategies of prevention
}

\author{
Tim S. Nawrot • Jan A. Staessen • Harry A. Roels • \\ Elke Munters • Ann Cuypers - Tom Richart • Ann Ruttens • \\ Karen Smeets $\cdot$ Herman Clijsters $\cdot$ Jaco Vangronsveld
}

Received: 7 December 2009/Accepted: 8 May 2010/Published online: 3 June 2010

(C) Springer Science+Business Media, LLC. 2010

\begin{abstract}
We focus on the recent evidence that elucidates our understanding about the effects of cadmium $(\mathrm{Cd})$ on human health and their prevention. Recently, there has been substantial progress in the exploration of the shape of the Cd concentrationresponse function on osteoporosis and mortality. Environmental exposure to $\mathrm{Cd}$ increases total mortality in a continuous fashion without evidence of a threshold, independently of kidney function and other
\end{abstract}

T. S. Nawrot $(\bowtie) \cdot$ E. Munters · A. Cuypers .

A. Ruttens $\cdot$ K. Smeets $\cdot$ H. Clijsters $\cdot$ J. Vangronsveld Centre for Environmental Sciences, Hasselt University, Diepenbeek, Belgium

e-mail: tim.nawrot@uhasselt.be

T. S. Nawrot

School of Public Health, KULeuven, Leuven, Belgium

\section{J. A. Staessen · T. Richart}

Study Coordinating Centre, Department of Cardiovascular Diseases, KULeuven, Leuven, Belgium

J. A. Staessen · T. Richart

Unit of Epidemiology, Maastricht University, Maastricht, The Netherlands

\section{H. A. Roels}

Louvain Centre for Toxicology and Applied Pharmacology, Université catholique de Louvain, Brussels, Belgium

\section{A. Ruttens}

CODA, Centre for Agrochemistry, Tervuren, Belgium classical factors associated with mortality including age, gender, smoking and social economic status. Pooled hazard rates of two recent environmental population based cohort studies revealed that for each doubling of urinary $\mathrm{Cd}$ concentration, the relative risk for mortality increases with $17 \%$ (95\% CI 4.2-33.1\%; $P<0.0001)$. Tubular kidney damage starts at urinary $\mathrm{Cd}$ concentrations ranging between 0.5 and $2 \mu \mathrm{g}$ urinary $\mathrm{Cd} / \mathrm{g}$ creatinine, and recent studies focusing on bone effects show increased risk of osteoporosis even at urinary $\mathrm{Cd}$ below $1 \mu \mathrm{g} \mathrm{Cd} / \mathrm{g}$ creatinine. The non-smoking adult population has urinary $\mathrm{Cd}$ concentrations close to or higher than $0.5 \mu \mathrm{g} \mathrm{Cd} / \mathrm{g}$ creatinine. To diminish the transfer of $\mathrm{Cd}$ from soil to plants for human consumption, the bioavailability of soil $\mathrm{Cd}$ for the plants should be reduced (external bioavailability) by maintaining agricultural and garden soils $\mathrm{pH}$ close to neutral $\left(\mathrm{pH}-\mathrm{H}_{2} \mathrm{O}\right.$ of 7.5 ; $\mathrm{pH}-$ $\mathrm{KCL}$ of 6.5). Reducing the systemic bioavailability of intestinal $\mathrm{Cd}$ can be best achieved by preserving a balanced iron status. The latter might especially be relevant in groups with a lower intake of iron, such as vegetarians, and women in reproductive phase of life. In exposed populations, house dust loaded with $\mathrm{Cd}$ is an additional relevant exposure route. In view of the insidious etiology of health effects associated with low dose exposure to $\mathrm{Cd}$ and the current European $\mathrm{Cd}$ intake which is close to the tolerable weekly intake, one should not underestimate the importance of the recent epidemiological evidence on Cd toxicity as to its medical and public health implications. 
Keywords Cadmium · Epidemiology · Kidney · Prevention · Mortality · Osteoporosis · Toxic metals

\section{Introduction}

Cadmium (Cd) is an ever-present and global environmental pollutant. During the twentieth century, the $\mathrm{Cd}$ concentration in human bones rose 10-fold in France (Jaworowski et al. 1985). Populations worldwide have a low-level intake through their food, causing an age-related cumulative increase in the body burden of this toxic metal (Järup et al. 1998c). Environmental exposure levels to $\mathrm{Cd}$, that are substantially above the background, occur in areas with current or historical industrial contamination for instance in regions of Belgium, Sweden, UK, Japan, and China.

We review the most substantial lines of research that recently (since 1999) have been pursued and elucidate our understanding about human health effects of $\mathrm{Cd}$ at the population level. Hence, we describe possible strategies of prevention for populations at risk.

\section{External and internal exposure to $\mathbf{C d}$}

Exposure to $\mathrm{Cd}$ occurs through intake of contaminated food or water, or by inhalation of polluted air. Occupational exposures are found in industries such as electroplating, welding, smelting and refining, pigment production, and battery manufacturing. Other respiratory exposure to $\mathrm{Cd}$ can occur through inhalation of cigarette smoke (Järup et al. 1998c) or indoor dust contaminated with $\mathrm{Cd}$ (Hogervorst et al. 2007).

In the non-anthropogenic influenced environment, Cd concentration is generally low and is no related with the concentration of other elements except zinc. Daily human intakes are from $10 \mu \mathrm{g} \mathrm{Cd} / \mathrm{kg}$ body weight (humans exposed to high $\mathrm{Cd}$ concentrations) to $0.1 \mu \mathrm{g} / \mathrm{kg}$ b.w. (Järup et al. 1998c). In order to keep the urinary $\mathrm{Cd}$ concentration below $1 \mu \mathrm{g} \mathrm{Cd} / \mathrm{g}$ creatinine in $95 \%$ of the population by age of 50 years, a weekly dietary Cd exposure should stay below $2.5 \mu \mathrm{g}$ Cd kg body-weight (CONTAM 2009).
The average dietary intake of $\mathrm{Cd}$ in adults across European countries was estimated to be between 1.9 and $3.0 \mu \mathrm{g} / \mathrm{kg}$ b.w. per week, and the highly exposed adults have estimates in the range of $2.5-3.9 \mu \mathrm{g} / \mathrm{kg}$ b.w. per week (CONTAM 2009). The CONTAM Panel noted that such average dietary intake in European countries is close to or slightly exceeding the threshold of $2.5 \mu \mathrm{g} / \mathrm{kg}$ b.w. (CONTAM 2009). Furthermore, it was noticed that subgroups of the population, such as vegetarians, women in reproductive phase of life, smokers and people living in highly contaminated areas may exceed the tolerably weekly intake by about 2 -fold.

$\mathrm{Cd}$ inhalation is a far smaller contributor to total $\mathrm{Cd}$ body burden except in some industrial settings, smokers or highly environmentally exposed subjects. Smokers absorb amounts of $\mathrm{Cd}$ comparable to those from food, about 1-3 $\mu \mathrm{g}$ of $\mathrm{Cd}$ per day. It has been reported that one cigarette contains about $1-2 \mu \mathrm{g}$ of $\mathrm{Cd}$ and that about $10 \%$ of the $\mathrm{Cd}$ content is inhaled when the cigarette is smoked (Nordberg et al. 2007). A logic preventive measure is to stop smoking and to avoid passive exposure to tobacco smoke (Bolte et al. 2008). Recent data show low $\mathrm{Cd}$ concentrations $\left(<5 \mathrm{ng} \mathrm{Cd} / \mathrm{m}^{3}\right)$ in the air of most European cities (Nawrot et al. 2009), however, close to some metallurgic plants values exceeding the WHO limit value $\left(5 \mathrm{ng} \mathrm{Cd} / \mathrm{m}^{3}\right)$ are still reported (e.g. measuring station 0BE01, Beerse, Belgium, $27 \mathrm{ng} \mathrm{Cd} / \mathrm{m}^{3}$; http://www.vmm.be, accessed on November, 2009). Belgium is no exception, and similar levels of environmental exposure likely persist in the United States and other European countries close to non-ferrous sites.

Soil polluted with $\mathrm{Cd}$, can be taken up by the wind and thereby generating polluted dust particles. The particles that contain $\mathrm{Cd}$ are generally bigger than $10 \mu \mathrm{m}$. They are too large to reach the lung alveoli, but they will end up in the gastrointestinal tract by mucociliary clearance from the naso-pharynx and bronchi (Alfaro-Moreno et al. 2007). One can prevent this way of $\mathrm{Cd}$ exposure by installing a well-closed cover of plants on the contaminated soils. House dust historically enriched by $\mathrm{Cd}$ is a relevant route of exposure in polluted areas (Hogervorst et al. 2007). In a population living in the vicinity of zinc refiners, a 2fold increase in the metal loading rate in house dust was associated with increases in blood $\mathrm{Cd}(+2.3 \%)$ and urinary $\mathrm{Cd}(+3.0 \%)$, independent of the intake of 
locally grown vegetables (Hogervorst et al. 2007). Gastrointestinal absorption of $\mathrm{Cd}$ is estimated to be around 5-8\%, but may increase in cases of iron deficiency (Flanagan et al. 1978). Inhalation absorption of $\mathrm{Cd}$ is generally higher than gastrointestinal absorption. It ranges $10-50 \%$, however, the absorption of $\mathrm{Cd}$ from cigarette smoke is between 25 and $50 \%$ (Nordberg et al. 2007).

Once absorbed, Cd binds avidly to metallothionein. $\mathrm{Cd}$ is stored mainly in the kidneys and the liver, and also in testes. The half-life in the body is 10-30 years. In general, nonsmokers have urinary $\mathrm{Cd}$ concentrations of $0.02-0.7 \mu \mathrm{g} / \mathrm{g}$ creatinine, which increase with age in parallel with the accumulation of Cd in the kidney (Järup et al. 1998c; Staessen et al. 2001).

Urinary excretion of $\mathrm{Cd}$ is a biomarker of lifetime $\mathrm{Cd}$ exposure. $\mathrm{Cd}$ excretion in 24-h urine is rather stable in solute composition and is therefore the gold standard to measure $\mathrm{Cd}$ in the urinary matrix. However, a lower participation rate and/or incomplete sampling together with practical reasons might incite to choose for spot urine. As spot urine samples vary in dilution of the solute within individuals, often urinary analytes are standardized to $1 \mathrm{~g}$ of creatinine. However, creatinine might be influenced by muscle mass, physical exercise, and the dietary intake of proteins. The mean urinary $\mathrm{Cd}$ level in the US population averaged $0.18 \mu \mathrm{g} / \mathrm{g}$ creatinine $(95 \mathrm{th}$ percentile: $0.79 \mu \mathrm{g} / \mathrm{g}$ creatinine) (CDC 2005). In the Belgian population urinary $\mathrm{Cd}$ averaged $0.80 \mu \mathrm{g} / \mathrm{g}$ creatinine to $1.00 \mu \mathrm{g} / \mathrm{g}$ creatinine for those in the vicinity of zinc smelters (Nawrot et al. 2008). Japanese women living in non-polluted areas had urinary $\mathrm{Cd}$ concentrations that were considerably higher and ranged from 0.25 to $11.4 \mu \mathrm{g} / \mathrm{g}$ creatinine (with a geometric mean of $2.87 \mu \mathrm{g} / \mathrm{g}$ creatinine) (Ezaki et al. 2003). Recent biomonitoring in a population living close to mining sites of Katanga (Congo) revealed urinary $\mathrm{Cd}$ values of $0.75 \mu \mathrm{g} / \mathrm{g}$ creatinine (Banza et al. 2009).

The Cd level in blood mainly reflects the last few months of exposure. Differences in hematocrit levels may cause some variability of the $\mathrm{Cd}$ concentration in whole blood. Hematocrit levels in women range normally from 35 to $47 \%$ and for men from 39 to $50 \%$. To control for this variability, whole blood $\mathrm{Cd}$ may be standardized for hematocrit. Non-smoking adults living in non-polluted areas have blood $\mathrm{Cd}$ concentrations that vary between 0.1 and $1.0 \mu \mathrm{g} \mathrm{Cd} / \mathrm{l}$ in whole blood.

\section{Cd related morbidity}

\section{Osteoporosis}

Osteoporosis is usually an age-related bone disorder. Evidence accumulates that besides kidney the bone is a primary target organ of $\mathrm{Cd}$ toxicity as well. Clinical features associated with osteoporosis include increased morbidity (pain, physical impairment, decreased quality of life), increased risk of new fractures and increased mortality (Van der Klift et al. 2002). Studies among populations from Belgium (Staessen et al. 1999; Schutte et al. 2008b), Sweden (Järup et al. 1998a; Alfvén et al. 2000; Åkesson et al. 2006), Japan (Honda et al. 2003) and China (Zhu et al. 2004; Jin et al. 2004; Wang et al. 2003) showed associations between osteoporosis and low-level environmental $\mathrm{Cd}$ exposure. The generally accepted interpretation has been that Cd-induced renal tubular damage (Staessen et al. 1994) decreases the calcium reabsorption in the nephron, resulting in hypercalciuria and decreased bone mineral density, and hence increased fracture risk (Järup et al. 1998c; Staessen et al. 1994) particularly in postmenopausal women (Schutte et al. 2008b; Staessen et al. 1999) or men in the older age group (Järup and Alfvén 2004). However, a recent study also found a dose-response association between odds of osteoporosis in young men (mean age 45) and urinary Cd (Nawrot et al. 2010). A selection of recent studies focusing on the association between $\mathrm{Cd}$ exposure and bone effects is given in Table 1.

A striking observation, considering the first epidemiological argument of Cd-induced bone effects, was the clear-cut interference of low-level $\mathrm{Cd}$ exposure with calcium metabolism. The Belgian Cadmibel study showed for a 2-fold increase in the urinary $\mathrm{Cd}$ excretion that the urinary calcium excretion rose on average by $0.25 \mathrm{mmol} / 24 \mathrm{~h}$ (Buchet et al. 1990). Hypercalciuria should be considered an early tubulotoxic effect, because it may exacerbate the development of osteoporosis, especially in the elderly. Some years later, mineral density and fracture incidence were assessed in 506 participants of the initial population cohort (Staessen et al. 1999). 


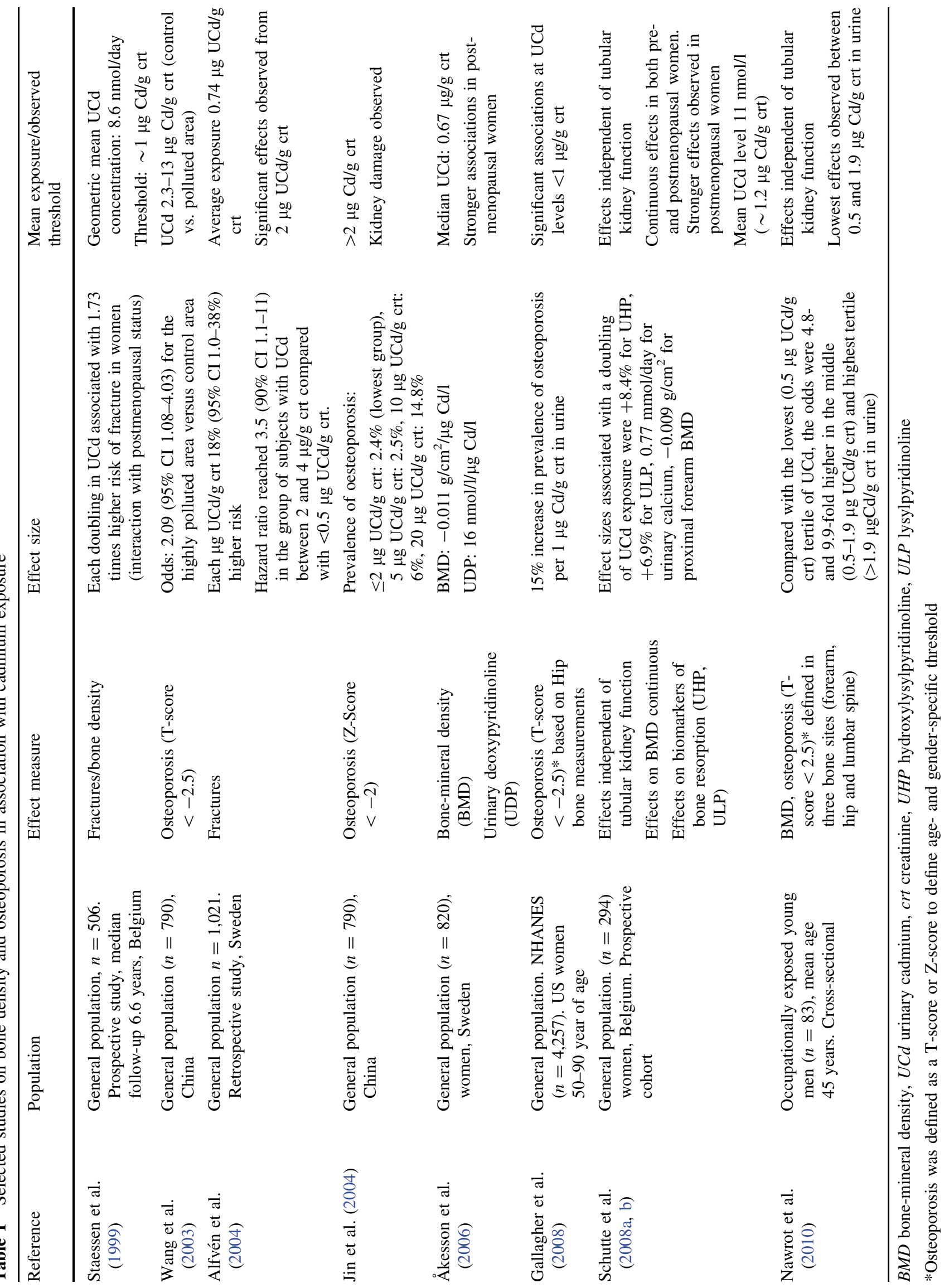


Cadmium was negatively associated with bone mineral density in postmenopausal women. A 2-fold increase in urinary $\mathrm{Cd}$ excretion at baseline was associated with $73 \%$ increased risk of fractures in women [95\% confidence interval (CI) 1.16-2.57]. The corresponding results for men were 1.20 (0.751.93) (Staessen et al. 1999). Data from Sweden showed a doubling of the risk for osteoporosis for urinary $\mathrm{Cd}$ levels of $0.5-3 \mu \mathrm{g} \mathrm{Cd} / \mathrm{g}$ creatinine (middle tertile) compared with the lowest tertile $(<0.5 \mu \mathrm{g} \mathrm{Cd} / \mathrm{g})$ (Alfvén et al. 2000). In addition, an increased risk of fractures was also noted in the Swedish Oscar study, demonstrating an elevated hazard ratio already at exposure levels of $2-4 \mu \mathrm{g} / \mathrm{g}$ creatinine (Alfvén et al. 2004). Studies in China have reported that osteoporosis is related to kidney dysfunction, especially to tubular damage and its severity (Wang et al. 2003; Jin et al. 2004). Although women are believed to be more susceptible than men, a study in middle-aged men (mean age 45 years) exposed to $\mathrm{Cd}$ in an occupational setting showed a dose-dependent increase of osteoporosis. This is the first study that assessed the bone mineral density at three sites on the skeleton including forearm, lumbar spine and hip. Osteoporosis was defined according to T-score less than -2.5 (in this case $<0.56 \mathrm{~g} / \mathrm{cm}^{2}$ ) in one of the measured bone sites. Compared with the lowest tertile of urinary $\mathrm{Cd}$, the risks were 4.8- and 9.9-fold higher in the middle $(0.51-1.88 \mu \mathrm{g} / \mathrm{g}$ creatinine $)$ and highest tertile $(>1.88 \mu \mathrm{g} / \mathrm{g}$ creatinine), respectively. Only four $(5 \%)$ men in this population had evidence of renal tubular dysfunction ( $\beta 2$-microglobuline $>300 \mu \mathrm{g} / \mathrm{g}$ creatinine) (Nawrot et al. 2010).

A study using data from National Health and Nutrition Examination Surveys (NHANES) reported an increased risk for hip osteoporosis in 3,207 women aged 50 years and older [OR $=1.43(95 \%$ CI $1.03-$ 2.0)] at urinary Cd levels between 0.50 and $1.00 \mu \mathrm{g} / \mathrm{g}$ creatinine as compared with the reference $(<0.5 \mu \mathrm{g} / \mathrm{g}$ creatinine) (Gallagher et al. 2008). Dose-response relationships were reported on urinary $\mathrm{Cd}$ as a continuous variable expressed in $\mu \mathrm{g}$ per g creatinine $[\mathrm{OR}=1.15$ (95\% CI 1.00-1.33)]. Recent data provide more insight into the mechanisms supporting a direct osteotoxic effect of $\mathrm{Cd}$ independent of the status of kidney function in that urinary excretion of pyridinium crosslinks from bone collagen is increased (Schutte et al. 2008b). The shape of this association was linear with effects observed at low levels (Table 1). The
Cd-induced bone effect is not mediated via impaired activation of vitamin D (Engstrom et al. 2009).

Kidney

Microproteins in urine are sensitive biomarkers of Cd-induced renal damage reflecting a tubulotoxic effect. Among them $\beta_{2}$ microglobulin, a small plasma protein, which passes the glomerular filter and subsequently almost completely reabsorbed in the renal tubules if no Cd-induced damage is present. Depending on the biomarker of nephrotoxicity thresholds of urinary $\mathrm{Cd}$ can range from about $2 \mu \mathrm{g} / \mathrm{g}$ creatinine for the onset of early biochemical alterations (e.g. hypercalciuria) to $10 \mu \mathrm{g} / \mathrm{g}$ creatinine for the development of the classic tubular microproteinuria (Roels et al. 1999). A cross-sectional analysis of 14,778 subjects (NHANES) showed that subjects in the highest quartile of blood $\mathrm{Cd}(>0.6 \mu \mathrm{g} / \mathrm{l})$ were almost two times more likely to exhibit albuminuria $(\geq 30 \mathrm{mg} / \mathrm{g}$ creatinine) and $32 \%$ more likely to have reduced glomerular filtration rate $\left(<60 \mathrm{ml} / \mathrm{min} / 1.73 \mathrm{~m}^{2}\right)$ (Navas-Acien et al. 2009).

Epidemiological evidence shows higher susceptibility for persons with diabetes to develop $\mathrm{Cd}$ induced renal dysfunction. A study of 122 men and women aged 18-85 exposed to $\mathrm{Cd}$ by consuming seafood (coast of Australia) found a statistically significant correlation between urinary $\mathrm{Cd}$ levels and albuminuria in individuals with type II diabetes, but found no such correlation in non-diabetic individuals (Haswell-Elkins et al. 2008). In 820 Swedish women between the ages of 53 and 64, multiple linear regression analysis showed statistically significant associations between urinary $\alpha 1$-microglobulin and urinary $\mathrm{Cd}$ with significant effect-modification for diabetes (Åkesson et al. 2005).

Although there is strong evidence that elevated levels of tubular biomarkers of renal dysfunction are associated with urinary cadmium, a surrogate of the $\mathrm{Cd}$ body burden, there is less agreement about the clinical significance and predictivity of these changes. Prospective epidemiological evidence from Belgium (Nawrot et al. 2008) and U.S. (Menke et al. 2009) suggests that the increased Cd related mortality was directly related to the toxic effects of $\mathrm{Cd}$, rather than being mediated by renal dysfunction, as suggested by the Japanese studies (Nishijo et al. 2006; Arisawa et al. 2007). 


\section{Diabetes}

The Third National Health and Nutrition Examination Survey (NHANES III), which examined 8,722 U.S. citizens over age 40 , revealed a significant association between elevations in urinary $\mathrm{Cd}$ levels and increases in fasting blood glucose levels (110-126 mg/dl) (Schwartz et al. 2003). To exclude the effect of tubular kidney function (defined as urine albumin, $\leq 30 \mu \mathrm{g}$ / $\mathrm{ml}$ ), the investigators restricted the analysis to persons without evidence of renal damage, but this restriction revealed the same conclusions. However, until now prospective evidence linking $\mathrm{Cd}$ exposure with higher prevalence of diabetes is lacking. Persons with diabetes appear to be more susceptible for the Cd-induced renal effects (see paragraph on kidney).

\section{Cancer}

Three lines of evidence explain why the International Agency for the Research on Cancer classified $\mathrm{Cd}$ as a human carcinogen. First, as reviewed by Verougstraete et al. (2003) several (Kazantzis et al. 1992; Sorahan and Lancashire 1997; Järup et al. 1998b; Sorahan and Waterhouse 1983) albeit not all studies (Sorahan et al. 1995) in workers showed a positive association between the risk of lung cancer and occupational exposure to $\mathrm{Cd}$. Figure 1 summarizes the findings of these five largest occupational cohort studies. The combined estimate showed an increased risk of $20 \%$ in workers exposed to Cd compared with those not exposed (Verougstraete et al. 2003). Second, data from rats showed that the pulmonary system is a target site for carcinogenesis after $\mathrm{Cd}$ inhalation. However, exposure to toxic metals in animal studies has usually been much higher than those reported in humans environmentally exposed to toxic metals. Third, several in vitro studies have shown plausible toxicodynamic pathways, such as increased oxidative stress (as reviewed in this special issue by Cuypers et al. 2010), modified activity of transcription factors (Watkin et al. 2003), and inhibition of DNA repair (Jin et al. 2003). Most errors that arise during DNA replication can be corrected by DNA polymerase proof reading or by postreplication mismatch repair. As reviewed in this special issue by Hartwig (2010), inactivation of the DNA repair machinery is an important primary effect, because repair systems are required to deal with the constant
DNA damage associated with normal cell function. The latter mechanism might indeed be relevant for environmental exposure because Jin et al. (2003) found that chronic exposure of yeast to environmentally relevant concentrations of $\mathrm{Cd}$ can result in extreme hypermutability. In this study, the DNAmismatch repair system was already inhibited by $28 \%$ at $\mathrm{Cd}$ concentrations as low as $5 \mu \mathrm{M}$. For example, the prostate of healthy unexposed humans accumulates $\mathrm{Cd}$ to concentrations of $12-28 \mu \mathrm{M}$ and human lungs of nonsmokers accumulate $\mathrm{Cd}$ to concentrations of $0.9-6 \mu \mathrm{M}$ (Jin et al. 2003). Further, in vitro studies provide evidence that $\mathrm{Cd}$ may act like an estrogen (Byrne et al. 2009), forming high-affinity complexes with estrogen receptors, suggesting a positive role in breast cancer carcinogenesis.

Along with this experimental evidence, recent epidemiological studies (Åkesson et al. 2008; Kellen et al. 2007; Kriegel et al. 2006; McElroy et al. 2006; Nawrot et al. 2006; van Wijngaarden et al. 2008; Vinceti et al. 2007), summarized in Table 2, gave important positive input into the discussion on the role of exposure to $\mathrm{Cd}$ in the development of cancer in humans. First, the results of a population-based case-control study noticed a significant 2-fold increased risk of breast cancer in women in the highest quartile of $\mathrm{Cd}$ exposure compared with those in the lowest quartile (McElroy et al. 2006). In a population based prospective cohort study with a median follow-up of 17.2 years in an area close to three zinc smelters, the association between incident lung cancer and urinary $\mathrm{Cd}$ was assessed (Nawrot et al. 2006). Cd concentration in soil ranged from 0.8 to $17.0 \mathrm{mg} / \mathrm{kg}$. At baseline, geometric mean urinary $\mathrm{Cd}$ excretion was $12.3 \mathrm{nmol} / \mathrm{day}(1.78 \mu \mathrm{g} / \mathrm{day})$ for people in the high-exposure area, compared with $7.7 \mathrm{nmol} /$ day $(0.87 \mu \mathrm{g} / \mathrm{day})$ for those in the reference (low exposure) area. The risk of lung cancer was 3.58 higher in the high exposure area compared to the area with low exposure. As already mentioned above, 24-h urinary excretion is a biomarker of lifetime exposure to $\mathrm{Cd}$. The risk for lung cancer was increased by $70 \%$ for a doubling of 24-h urinary $\mathrm{Cd}$ excretion. Confounding by co-exposure to arsenic was unlikely.

Epidemiological studies did not convincingly imply $\mathrm{Cd}$ as a cause of prostate cancer. Of 11 cohort studies, only three found a positive association (Verougstraete et al. 2003). However, a recent case-control study (Vinceti et al. 2007) with 40 
Fig. 1 Standardized mortality rates and $95 \% \mathrm{CI}$ for lung cancer for the five largest occupational cohort studies. Combined estimate denotes a meta-analysis of the five large cohort studies mentioned. Figure based on Verougstraete et al. (2003) (with permission)

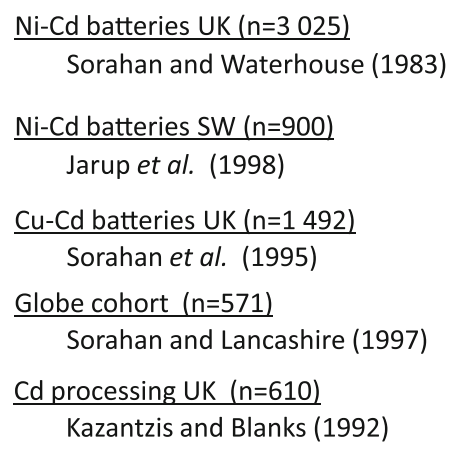

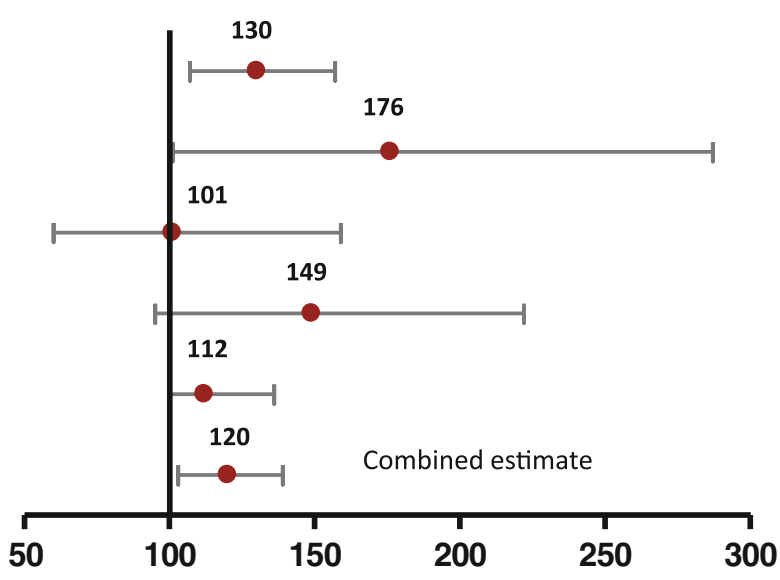

Table 2 Studies on cancer in association with environmental cadmium exposure

\begin{tabular}{|c|c|c|c|c|}
\hline Site & Reference & Population & Effect size & $\begin{array}{l}\text { Shape of the } \\
\text { association }\end{array}$ \\
\hline Breast & $\begin{array}{l}\text { McElroy et al. } \\
\text { (2006) }\end{array}$ & $\begin{array}{l}\text { Case-control study: } n=254 \\
\text { cases, } n=246 \text { controls, } \\
\text { United States, based on } \\
\text { NHANES sample }\end{array}$ & $\begin{array}{l}\text { Odds ratio: } 2.29 \text { (95\% CI } 1.3-4.2) \\
\text { comparing the highest quartile of urinary } \\
\mathrm{Cd}(\geq 0.58 \mu \mathrm{g} / \mathrm{g} \text { crt) to the lowest } \\
(<0.26 \mu \mathrm{g} / \mathrm{g} \mathrm{crt})\end{array}$ & $\begin{array}{l}\text { Continuous linear } \\
\text { increase in risk }\end{array}$ \\
\hline Endometrium & $\begin{array}{l}\text { Åkesson et al. } \\
\text { (2008) }\end{array}$ & $\begin{array}{l}\text { Cohort study: } 30,210 \text { post } \\
\text { menopausal women, } 16 \text { years } \\
\text { follow-up, Sweden }\end{array}$ & $\begin{array}{l}\text { Relative risk: } 1.39 \text { (95\% CI } 1.04-1.86 \text { ) for } \\
\text { highest tertile of intake of } \mathrm{Cd} \geq 16 \mu \mathrm{g} \mathrm{Cd} / \\
\text { day versus }<13.7 \mu \mathrm{g} \mathrm{Cd} / \text { day (lowest } \\
\text { tertile) }\end{array}$ & $\begin{array}{l}\text { Third tertile } \\
\text { significantly } \\
\text { different from } \\
\text { first. Shape linear }\end{array}$ \\
\hline Lung caner & $\begin{array}{l}\text { Nawrot et al. } \\
\text { (2006) }\end{array}$ & $\begin{array}{l}\text { Cohort study: } n=994,15 \text { years } \\
\text { follow-up, Belgium }\end{array}$ & $\begin{array}{l}\text { Relative risk } 1.31 \text { (95\% CI 1.03-1.65) for } \\
\text { doubling in urinary Cd }\end{array}$ & $\begin{array}{l}\text { Continuous linear } \\
\text { increase in risk }\end{array}$ \\
\hline Pancreas & $\begin{array}{l}\text { Kriegel et al. } \\
\text { (2006) }\end{array}$ & $\begin{array}{l}\text { Case-control study: } n=31 \\
\text { cases, } n=52 \text { controls, Egypt }\end{array}$ & $\begin{array}{l}\text { Odds ratio } 1.12 \text { (95\% CI 1.04-1.23) per } \mu \mathrm{g} / \mathrm{l} \\
\text { serum Cd. }\end{array}$ & $\begin{array}{l}\text { Continuous } \\
\text { increase risk }\end{array}$ \\
\hline \multirow[t]{2}{*}{ Prostate } & $\begin{array}{l}\text { Vinceti et al. } \\
\text { (2007) }\end{array}$ & $\begin{array}{l}\text { Case-control study: } n=45 \\
\text { cases, } n=58 \text { controls, Italy }\end{array}$ & $\begin{array}{l}\text { Odds ratio: } 4.7 \text { (95\% CI } 1.3-17.5) \text { for } \\
\text { highest quintile toenail } \mathrm{Cd}(\geq 0.031 \mu \mathrm{g} / \mathrm{g}) \\
\text { versus }<0.007\end{array}$ & $\begin{array}{l}\text { Threshold observed } \\
\sim 0.015 \mu \mathrm{g} / \mathrm{g} \\
\text { toenail } \mathrm{Cd}\end{array}$ \\
\hline & $\begin{array}{l}\text { Van } \\
\text { Wijngaarden } \\
\text { et al. (2008) }\end{array}$ & $\begin{array}{l}\text { Cross-sectional: } 320 \text { men, } \\
\text { NHANES population sample, } \\
\text { United States }\end{array}$ & $\begin{array}{l}\text { Significant Cd-zinc interaction: Men with } \\
\text { zinc intake }<12.7 \mathrm{mg} / \text { day a urinary Cd } \\
\text { increase of } 1 \mu \mathrm{g} / \mathrm{g} \text { crt is associated with a } \\
35 \% \text { increase in serum PSA }\end{array}$ & $\begin{array}{l}\text { Effect size depends } \\
\text { on zinc intake }\end{array}$ \\
\hline $\begin{array}{l}\text { Urinary } \\
\text { bladder }\end{array}$ & $\begin{array}{l}\text { Kellen et al. } \\
\text { (2007) }\end{array}$ & $\begin{array}{l}\text { Case-control study: } n=172 \\
\text { bladder cases, } n=359 \\
\text { controls, Belgium }\end{array}$ & $\begin{array}{l}\text { Odds ratio: } 5.7 \text { (95\% CI 5.0-13.8) } \\
\text { comparing the highest }(\geq 1 \mu \mathrm{g} / \mathrm{l}) \text { to the } \\
\text { lowest tertile }(<0.2 \mu \mathrm{g} / \mathrm{l}) \text { of blood } \mathrm{Cd}\end{array}$ & $\begin{array}{l}\text { Continuous linear } \\
\text { increase in risk }\end{array}$ \\
\hline
\end{tabular}

cases and 58 controls showed an excess cancer risk in subjects in the third and fourth (highest) quartiles (above $0.0145 \mu \mathrm{g} \mathrm{Cd} / \mathrm{g}$ ) of toenail $\mathrm{Cd}$ concentration $[\mathrm{OR}=1.3(95 \%$ CI $0.3-4.9)]$ and 4.7 [(95\% CI 1.317.5), respectively, $P$ trend $=0.004]$ compared with subjects in the bottom quartile. A study (van Wijngaarden et al. 2008) reported an association between serum levels of Prostate Specific Antigen (PSA) and Cd exposure. They found effect-modification by zinc on the urinary $\mathrm{Cd}$ and PSA association in the NHANES population sample including 1,320 men. An increase in urinary $\mathrm{Cd}$ by $1 \mu \mathrm{g} / \mathrm{g}$ creatinine was associated with a $35 \%$ increase in PSA levels, in subjects with a zinc intake below the median (12.7 $\mathrm{mg} /$ day). In a case-control study, pancreatic cancer was associated with serum Cd levels (Kriegel et al. 2006). For each $1 \mu \mathrm{g} \mathrm{Cd}$ per 1 serum increase, the odds for pancreatic cancer increased with $12 \%$ (Table 3). Åkesson et al. (2008) reported an odds ratio of 2.9 for endometrial cancer among women with $\mathrm{Cd}$ intake above highest tertile. In a study of bladder cancer, Kellen et al. (2007) showed a 5.7-fold 
Table 3 Selected studies on internal cadmium concentration in association with iron status

\begin{tabular}{|c|c|c|c|c|}
\hline Author & Population & $\mathrm{N}$ & Iron indicator & Associations \\
\hline $\begin{array}{l}\text { Berglund et al. } \\
\text { (1994) }\end{array}$ & $\begin{array}{l}\text { Non-Smoking women, } \\
\text { Sweden, 20-50 years }\end{array}$ & Women 57 & Log S-Ferritin & $\log \mathrm{BCd} r=-0.52, P<0.01$ \\
\hline $\begin{array}{l}\text { Olsson et al. } \\
\text { (2002) }\end{array}$ & $\begin{array}{l}\text { Men and women on farms } \\
\text { in Sweden }\end{array}$ & $\begin{array}{l}\text { Female Never- } \\
\text { Smokers } 38\end{array}$ & S-Ferritin & BCd $r=-0.52$ exponential association \\
\hline $\begin{array}{l}\text { Muneko Nishijo } \\
\text { et al. (2004) }\end{array}$ & $\begin{array}{l}\text { Pregnant Japanese women } \\
\text { 30-32 years }\end{array}$ & Women 50 & Iron-Intake (mg) & $\begin{array}{l}\text { BCd spearman } r=-0.35, P<0.05 \\
\text { UCd spearman } r=-0.28, \mathrm{~ns}\end{array}$ \\
\hline $\begin{array}{l}\text { Åkesson et al. } \\
\text { (2002) }\end{array}$ & $\begin{array}{l}\text { Early pregnant women } \\
\text { gestational week } 11 \\
20-45 \text { years, Sweden }\end{array}$ & $\begin{array}{l}\text { Women: } 210 \\
\text { Women } 188\end{array}$ & S-Ferritin & $\begin{array}{l}\text { BCd spearman } r=-0.23, P \leq 0.01 \\
\text { UCd spearman } r=-0.02 \mathrm{~ns}\end{array}$ \\
\hline $\begin{array}{l}\text { Nawrot et al. } \\
\text { (2008) }\end{array}$ & $\begin{array}{l}\text { Men and women in high and } \\
\text { low exposure area, Belgium }\end{array}$ & Men and women 711 & Log S-Ferritin & $\begin{array}{l}\text { Log } \mathrm{BCd} \text { regression coefficient }= \\
-0.110 \pm 0.024, P \leq 0.001\end{array}$ \\
\hline $\begin{array}{l}\text { Kippler et al. } \\
\text { (2009) }\end{array}$ & $\begin{array}{l}\text { Pregnant Bangladeshi women } \\
\text { in gestational week } 14 \\
\text { 14-44 years }\end{array}$ & Women 408 & S-Ferritin & Ery Cd spearman $r=-0.17, P<0.001$ \\
\hline
\end{tabular}

$B C d$ blood cadmium, $U C d$ urinary cadmium, Ery erythrocytes

increase in risk between subjects with blood $\mathrm{Cd}$ at the lowest tertile $(<0.2 \mu \mathrm{g} / \mathrm{l})$ versus the highest tertile $(\geq 1 \mu \mathrm{g} / \mathrm{l})$.

\section{Blood pressure and effects on arteries}

Chronic exposure to $\mathrm{Cd}$ not only leads to its accumulation in the kidneys and liver but also in the endothelium and vascular smooth muscle cells (Messner and Bernhard 2010; Messner et al. 2009). $\mathrm{Cd}$ and $\mathrm{Pb}$ at exposure levels encountered at the workplace or in the environment are suspected to increase blood pressure and to cause hypertension (Nawrot et al. 2008). However, the influence of $\mathrm{Cd}$ on the cardiovascular system remains controversial. Cross-sectional and prospective studies by Staessen et al. (2000) showed that conventional or 24-h ambulatory blood pressure, or the risk of hypertension or cardiovascular diseases risk (Nawrot et al. 2008) in environmentally exposed populations were not associated with 24-h urinary Cd. Subjects with Itai-Itai disease also failed to develop hypertension (Nakagawa and Nishijo 1996). A recent report of NHANES showed a lower odds ratio for hypertension in the highest urinary Cd quartile compared with the lowest (Tellez-Plaza et al. 2008). Kurihara et al. (2004) studied urinary Cd normalised for creatinine as a biomarker of exposure and reported a significant odds ratio for hypertension less than unity in both men [0.62 (95\% CI 0.42-0.92)] and women [0.67 (95\% CI 0.48-0.94)]. In contrast to these negative findings, Satarug et al. (2005) reported a positive association between blood pressure and urinary $\mathrm{Cd}$ in a population sample of 200 subjects that also showed tubular dysfunction. The association between blood pressure and cardiovascular risk is continuous without a threshold (Nawrot et al. 2003). Therefore, blood pressure should be treated as a continuous variable in epidemiological research rather than as arbitrary thresholds reflecting hypertension. Nevertheless, both at a continuous or a dichotomous (hypertension) scale there is no clear evidence for "pressor" effect due to environmentally $\mathrm{Cd}$ exposure.

Recently, NHANES data linked Cd with cardiovascular outcomes and peripheral arterial disease. Navas-Acien et al. $(2004,2005)$ reported that peripheral arterial disease might be associated with blood and urinary $\mathrm{Cd}$, thus suggesting that $\mathrm{Cd}$ is involved in arterial dysfunction. The authors used the anklebrachial index to reflect peripheral arterial disease. This non-invasive measure is useful in assessing the patency of the leg arteries and predicts cardiovascular morbidity and mortality (Resnick et al. 2004). After accounting for traditional cardiovascular risk factors, the odds ratio of peripheral arterial disease showed significant increase in the odds 2.82 (95\% CI 1.36$5.85)$ for the highest blood Cd quartile $(>6.23 \mathrm{nmol} / \mathrm{l}$ or $0.70 \mu \mathrm{g} / \mathrm{l})$ compared with the lowest quartile $(\leq 3.56 \mathrm{nmol} / 1$ or $0.40 \mu \mathrm{g} / \mathrm{l})$ (Navas-Acien et al. 
2004). This epidemiologic association is in line with data of the Atherosclerosis Risk Factors in Female Youngsters (ARFY) study, where blood Cd level was independently associated with early atherosclerotic vessel wall thickening [intima-media thickness exceeding the 90th percentile of the distribution; OR 1.6 (1.1-2.3)] (Messner et al. 2009). In contrast to these studies the Belgian populations did not show correlations between measures of arterial function and blood $\mathrm{Cd}$ and failed to confirm that increased $\mathrm{Cd}$ body burden (determined by 24-h urinary Cd excretion) was associated with decreased arterial function (Schutte et al. 2008a; Plusquin et al. 2005). Aortic pulse wave velocity, which is the gold standard of arterial stiffness, was significantly and inversely associated with 24-h urinary cadmium excretion (Schutte et al. 2008a).

\section{Reproduction}

No difference was found in fertility between men occupationally exposed to $\mathrm{Cd}$ and an appropriately matched control group $(n=118)$ by assessing birth experiences of their wives (Gennart et al. 1992). However, a hospital sample of the general population with infertility problems showed that blood and seminal Cd were significantly higher among infertility patients than controls (median seminal plasma $\mathrm{Cd}$ was $0.282 \mu \mathrm{g} / 1$ in infertility patients vs. $0.092 \mu \mathrm{g} / 1$ in controls). The percentage of motile sperm and sperm concentration correlated inversely with seminal plasma Cd among the infertility patients $(r=-0.20$, $P<0.04$ ) (Benoff et al. 2009).

\section{Prospective mortality studies}

Recently, two population based cohort studies (Menke et al. 2009; Nawrot et al. 2008) showed higher risk for death in association with $\mathrm{Cd}$ exposure. The average urinary $\mathrm{Cd}$ concentration at baseline was about three times higher in the Belgian cohort $(\sim 1 \mu \mathrm{g} / \mathrm{g}$ creatinine) compared with the US cohort. The hazard ratios (95\% CI) for all-cause mortality, associated with a 2-fold higher urinary Cd were 1.28 (95\% CI 1.151.43 ) in men and 1.06 (95\% CI 0.96-1.16) for women in the US cohort (NHANES III) and 1.20 (95\% CI 1.04-1.39) in the men and women combined in the Belgian cohort. In the Belgian cohort the hazard rates were not different between men and women (no urinary $\mathrm{Cd}$ by gender interaction in relation to mortality observed). Meta-regression of these three hazard ratios by a random effect model revealed a $17 \%$ (95\% CI $4.1-33.2 \% ; P<0.0001)$ increase in the relative risk associated with a doubling of the urinary $\mathrm{Cd}$ concentration. The cause-related mortality pattern differed between the two cohorts. In the Belgian cohort deaths from non-cardiovascular but not cardiovascular causes increased with higher 24-h urinary Cd excretion (Nawrot et al. 2008). In the NHANES study, both noncardiovascular and cardiovascular disease increased with higher urinary $\mathrm{Cd}$ concentrations in men whereas in women non-cardiovascular disease were borderline significantly associated but not cardiovascular mortality.

Previous studies in Japanese populations, showed associations between mortality and environmental exposure to Cd (Arisawa et al. 2007; Nishijo et al. 2006). However, there are important differences between the Japanese observations and the recent population based findings in the US and Belgium. First, the median urinary $\mathrm{Cd}$ level in the Japanese studies was $7.0 \mu \mathrm{g} / \mathrm{g}$ creatinine (Arisawa et al. 2007), which probably explains the increased mortality from nephritis and nephrosis (Nishijo et al. 2006). By comparison, the median urinary $\mathrm{Cd}$ at baseline was $\sim 1 \mu \mathrm{g} / \mathrm{g}$ creatinine in Belgium and $\sim 0.34 \mu \mathrm{g} / \mathrm{g}$ creatinine $(0.28$ in men and $0.40 \mu \mathrm{g} / \mathrm{g}$ creatinine in women) in the NHANESIII survey.

\section{Prevention}

Preventive measures that might diminish the $\mathrm{Cd}$ containing dust in our homes would be to replace carpets with floor coverings that can be cleaned with water. One may use a vacuum cleaner with a HEPAfilter combined with cyclone technology to remove particles as small as $0.3 \mu \mathrm{m}$ to prevent small Cd-loaded particles from being remitted into the air (Yiin et al. 2002). For most of these preventive measures no hard scientific evidence based on intervention studies exists. Until now, only one intervention study has been reported (Kobayashi et al. 2008). A study in 50 persons, with urinary cadmium measured before and after soil replacement of a Cd-polluted rice basin, showed 10 years after soil replacement a decrease of $40 \%$ in urinary cadmium excretion, but the degree of renal tubular 
injury (as reflected by $\beta 2$-microglobulin, retinol binding protein (RBP), total protein, amino-N and glucose) did not improve.

Bioavailability of $\mathrm{Cd}$ in the soil and its transfer to plants

In the general nonsmoking population, not living in a $\mathrm{Cd}$ polluted area, the diet is the main source of $\mathrm{Cd}$ exposure. Most foods contain low concentrations of $\mathrm{Cd}$, but high concentrations may be found in mushrooms, liver, kidney, and shellfish. Cereals, especially the non-refined wheat products, rice and vegetables, often contain elevated $\mathrm{Cd}$ concentrations. It seems likely that vegetarians have an increased intake of $\mathrm{Cd}$.

Plant species and varieties differ extensively in their capacity to absorb and accumulate toxic metals. Lettuce, spinach, celery and cabbage (leaf vegetables) tend to accumulate relatively high concentrations of $\mathrm{Cd}$, whereas beans (and other 'fruit vegetables') accumulate only low amounts of Cd. In two areas in the North of Belgium, home grown vegetables showed levels that exceeded the European limit (Fig. 2) with exception of beans and other 'fruit vegetables'. Even in the reference area, with soil Cd levels that averaged $0.9 \mathrm{mg} / \mathrm{kg}$ soil, Cd content in about $50 \%$ of the celery were above the EU limit. Indeed, also in the nonpolluted range (Cd levels below $1 \mathrm{mg} \mathrm{Cd} / \mathrm{kg}$ soil) the transfer of $\mathrm{Cd}$ from the soil to plants is closely related with soil pH (Fig. 3). To know whether it is safe to grow vegetables in polluted areas, a representative soil sample should be taken to determine the soil $\mathrm{Cd}$ concentrations. Soil $\mathrm{pH}$ testing is necessary to establish the "lime requirement" of the soil. Natural forms of calcium carbonate are used to lime gardening and agricultural soils. Ground lime should be applied on a regular basis to maintain soil alkalinity, thereby reducing $\mathrm{Cd}$ uptake by plants. Table 4 lists the maximal allowable soil Cd level with respect to the grown vegetable. On the premise that the soil $\mathrm{pH}$ is high enough $\left(\mathrm{pH}-\mathrm{H}_{2} \mathrm{O}\right.$ of $7.5 ; \mathrm{pH}-\mathrm{KCl}$ of 6.5$)$ it is unlikely that vegetables grown on these specific soil $\mathrm{Cd}$ levels will exceed the EU limit value for $\mathrm{Cd}$.

Bioavailability of $\mathrm{Cd}$ in the intestine and its transfer to blood

The amount of intestinally absorbed $\mathrm{Cd}$ is proportional to the $\mathrm{Cd}$ concentration in the food. However,

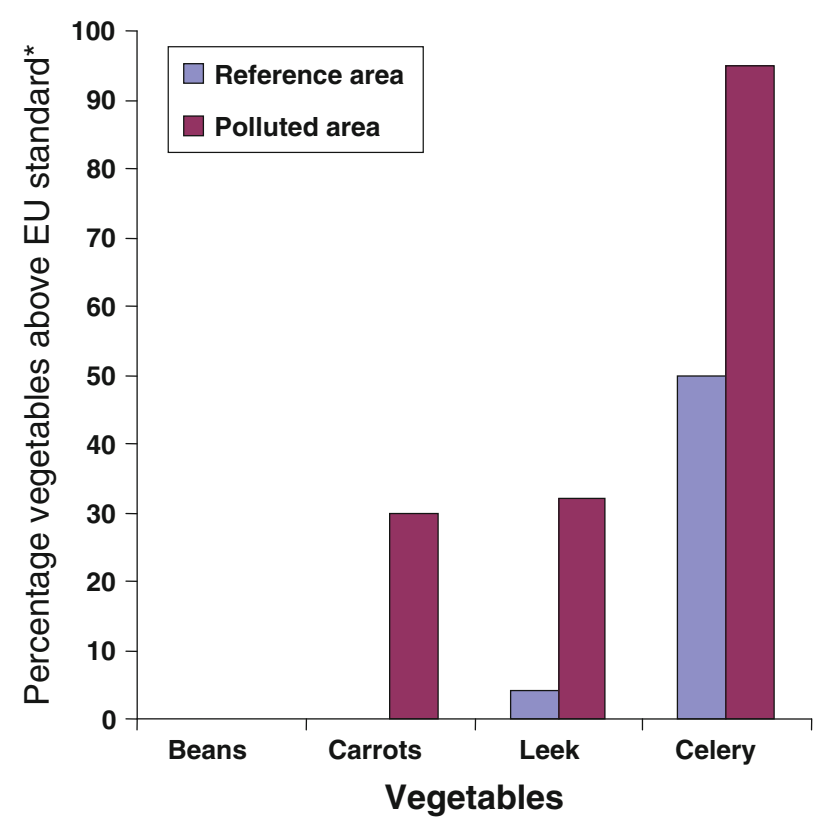

Fig. 2 Home grown vegetables from 127 households that grew vegetables and provided samples of beans, carrots, leek and celery. Vegetables were dried for $24 \mathrm{~h}$ at $60^{\circ} \mathrm{C}$, incinerated at low temperature, digested with $3 \mathrm{~mol} / \mathrm{l}$ hydrochloric acid and measured for cadmium by atomic absorption spectrometry. The geometric mean soil cadmium concentration was 5.8 times higher in the polluted area and averaged (5th-95th percentile interval) $0.9 \mathrm{mg} / \mathrm{kg}$ soil $(0.4-1.6)$ in the low polluted area and $5.3 \mathrm{mg} / \mathrm{kg}(1.4-18.9)$ in the high polluted area $(P<0.0001)$. European limit values are $2 \mathrm{mg} / \mathrm{kg}$ (dry weight) for leafy vegetables and $0.9 \mathrm{mg} / \mathrm{kg}$ for all others

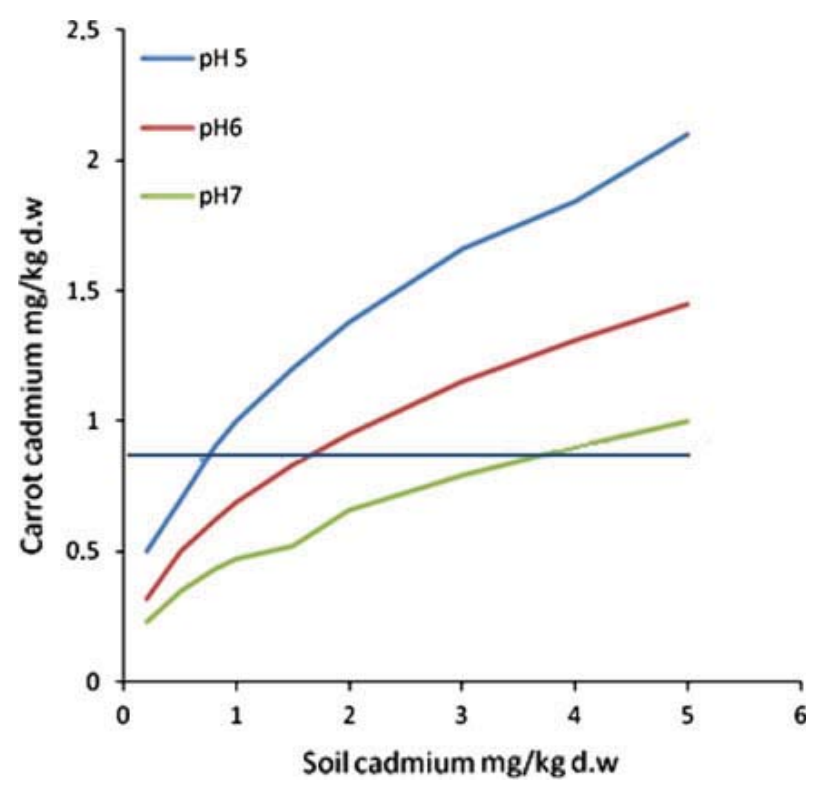

Fig. 3 Cadmium concentration in carrots in relation to the cadmium concentration and $\mathrm{pH}$ of the soil. Line denotes the EU limit value of $0.9 \mathrm{mg} / \mathrm{kg}$ d.w. (dry weight). $\mathrm{pH}$ based on $\mathrm{pH}-\mathrm{H}_{2} \mathrm{O}$ 
Table 4 Maximal allowable soil cadmium levels depending on the grown vegetables

\begin{tabular}{lll}
\hline $2 \mathrm{mg} / \mathrm{kg}^{*}$ & $5 \mathrm{mg} / \mathrm{kg}^{*}$ & $10 \mathrm{mg} / \mathrm{kg}^{*}$ \\
\hline Endives & Potatoes & Beans \\
Chervil & Strawberries & Peas \\
Parsley & Cauliflowers & Paprika \\
Rhubarb & Leeks & Tomato \\
Lettuce & Radishes & \\
Spinach & Salsify & \\
Watercress & Shallots & \\
Garden cress & Chicory & \\
Corn salad & Carrots & \\
Celery & Onion & \\
\hline
\end{tabular}

Maximal allowable soil concentrations for vegetable species that will not exceed

The EU guideline value for vegetables if the soil $\mathrm{pH}$ is high enough ( $\mathrm{pH}-\mathrm{H}_{2} \mathrm{O}$ of 7.5; pH-KCL of 6.5)

there are factors that influence the rate of intestinal absorption of $\mathrm{Cd}$. The rate of $\mathrm{Cd}$ absorption is increased if the nutritional status of calcium, iron or zinc is low. The duodenal iron transporter is upregulated by iron deficiency, which leads to an increased intestinal absorption of dietary $\mathrm{Cd}$. This is probably the main reason why the body burden of $\mathrm{Cd}$ is generally higher among women (Menke et al. 2009; Vahter et al. 2007) whose prevalence of iron depletion is higher than that of men. Urinary $\mathrm{Cd}$ increases longitudinally among pregnant women with exhausted iron stores (soluble transferrin receptor-serum ferritin ratio above 500) (Åkesson et al. 2002). The increase in urinary $\mathrm{Cd}$ with age is more pronounced in multiparous than in nullparous women (Åkesson et al. 2002). Table 3 lists recent studies linking iron status with blood and urine $\mathrm{Cd}$. Most of the studies (Åkesson et al. 2002; Berglund et al. 1994; Kippler et al. 2009; Nawrot et al. 2008; Nishijo et al. 2004; Olsson et al. 2002) found a significant increase in body $\mathrm{Cd}$ stores in individuals with lower iron status. In Europe, iron deficiency is considered to be one of the main nutritional deficiency disorders affecting large fractions of the population, including, pre-postmenopausal and pregnant women. About $20 \%$ of young women have iron deficiency (serum ferritin $<15 \mu \mathrm{g} / \mathrm{l}$ ) (Grondin et al. 2008).

\section{Conclusions}

There has been substantial progress in the evaluation of the health effects of $\mathrm{Cd}$ and in the exploration of the shape of the concentration-response function at different organ systems. These results have important scientific, medical, and public health implications. To significantly reduce the adverse health effects of exposure to a toxic metal like $\mathrm{Cd}$, the heart of the matter remains that further efforts must be made to reduce $\mathrm{Cd}$ pollution by appropriate legislation and its enforcement. However, in historically polluted areas, specific preventive strategies including covering of the polluted soil and restrictions to gardening and agriculture activities might be crucial depending on the concentrations and soil characteristics. The mean exposure for adults across Europe is close to the tolerable weekly intake of $2.5 \mu \mathrm{g} / \mathrm{kg}$ body weight. Subgroups such as vegetarians, children, smokers and people living in highly contaminated areas may exceed the tolerable weekly intake about 2 -fold. To diminish the transfer of $\mathrm{Cd}$ from soil to plants, the soil $\mathrm{Cd}$ bioavailability should be reduced by maintaining agricultural and garden soil $\mathrm{pH}$ close to neutral. Balanced iron intake is effective in reducing the bioavailability of $\mathrm{Cd}$ present in the intestine, by reducing its absorption. Along with the recent knowledge concerning low dose $\mathrm{Cd}$ exposure, the current exposure to $\mathrm{Cd}$ at the population level should be kept as low as possible so that the urinary $\mathrm{Cd}$ concentration is kept below $0.66 \mu \mathrm{g} / \mathrm{g}$ creatinine (margin of safety $=3$ ) as proposed by the EU(European Community report, EUR 23424 EN). The relations we discussed here between internal $\mathrm{Cd}$ dose and morbidity and mortality are based on individual data and satisfy Hill's criteria for causality (Hill 1965).

Acknowledgement The Environmental Health research at Hasselt University is supported by grants from the Flemish Fund for Scientific Research (FWO, krediet aan navorsers to T.N.) and internal Hasselt University grants (Bijzonder Onderzoekdsfonds, BOF).

\section{References}

Åkesson A, Berglund M, Schutz A, Bjellerup P, Bremme K, Vahter M (2002) Cadmium exposure in pregnancy and lactation in relation to iron status. Am J Public Health 92:284-287 
Åkesson A, Lundh T, Vahter M, Bjellerup P, Lidfeldt J, Nerbrand C, Samsioe G, Stromberg U, Skerfving S (2005) Tubular and glomerular kidney effects in Swedish women with low environmental cadmium exposure. Environ Health Perspect 113:1627-1631

Åkesson A, Bjellerup P, Lundh T, Lidfeldt J, Nerbrand C, Samsioe G, Skerfving S, Vahter M (2006) Cadmiuminduced effects on bone in a population-based study of women. Environ Health Perspect 114:830-834

Åkesson A, Julin B, Wolk A (2008) Long-term dietary cadmium intake and postmenopausal endometrial cancer incidence: a population-based prospective cohort study. Cancer Res 68:6435-6441

Alfaro-Moreno E, Nawrot TS, Nemmar A, Nemery B (2007) Particulate matter in the environment: pulmonary and cardiovascular effects. Curr Opin Pulm Med 13: 98-106

Alfvén T, Elinder CG, Carlsson MD, Grubb A, Hellstrom L, Persson B, Pettersson C, Spang G, Schutz A, Järup L (2000) Low-level cadmium exposure and osteoporosis. J Bone Miner Res 15:1579-1586

Alfvén T, Elinder CG, Hellstrom L, Lagarde F, Järup L (2004) Cadmium exposure and distal forearm fractures. J Bone Miner Res 19:900-905

Arisawa K, Uemura H, Hiyoshi M, Dakeshita S, Kitayama A, Saito H, Soda M (2007) Cause-specific mortality and cancer incidence rates in relation to urinary beta2-microglobulin: 23-year follow-up study in a cadmium-polluted area. Toxicol Lett 173:168-174

Banza CL, Nawrot TS, Haufroid V, Decree S, De PT, Smolders E, Kabyla BI, Luboya ON, Ilunga AN, Mutombo AM, Nemery B (2009) High human exposure to cobalt and other metals in Katanga, a mining area of the Democratic Republic of Congo. Environ Res 109:745-752

Benoff S, Hauser R, Marmar JL, Hurley IR, Napolitano B, Centola GM (2009) Cadmium concentrations in blood and seminal plasma: correlations with sperm number and motility in three male populations (infertility patients, artificial insemination donors, and unselected volunteers). Mol Med 15:248-262

Berglund M, Åkesson A, Nermell B, Vahter M (1994) Intestinal absorption of dietary cadmium in women depends on body iron stores and fiber intake. Environ Health Perspect 102:1058-1066

Bolte G, Heitmann D, Kiranoglu M, Schierl R, Diemer J, Koerner W, Fromme H (2008) Exposure to environmental tobacco smoke in German restaurants, pubs and discotheques. J Expo Sci Environ Epidemiol 18:262-271

Buchet JP, Lauwerys R, Roels H, Bernard A, Bruaux P, Claeys F, Ducoffre G, de PP, Staessen J, Amery A (1990) Renal effects of cadmium body burden of the general population. Lancet 336:699-702

Byrne C, Divekar SD, Storchan GB, Parodi DA, Martin MB (2009) Cadmium - a metallohormone? Toxicol Appl Pharmacol 238:266-271

Centers for Disease Control and Prevention (CDC) (2005) Third national report on human exposure to environmental chemicals. NCEH 05-0570, Atlanta, GA, 21 August 2008, pp 1-467. http://www.cdc.gov/exposurereport/pdf/third report.pdf. Accessed November 2010
CONTAM (2009) Scientific opinion of the panel on contaminants in the food chain on a request from the European commission on cadmium in food. EFSA J 980:1-139

Cuypers A, Plusquin M, Remans T, Jozefczak M, Keunen E, Gielen H, Opdenakker K, Nair AR, Munters E, Artois TJ, Nawrot T, Vangronsveld J, Smeets K (2010) Cadmium stress: an oxidative challenge. Biometals. doi:10.1007/ s10534-010-9329-x

Engstrom A, Skerving S, Lidfeldt J, Burgaz A, Lundh T, Samsioe G, Vahter M, Akesson A (2009) Cadmiuminduced bone effect is not mediated via low serum 1, 25dihydroxy vitamin D. Environ Res 109:188-192

European Community Report (EUR 23424 EN) http://ecb. jrc.ec.europa.eu/Documents/Existing-Chemicals/RISK_ ASSESSMENT/SUMMARY/cdmetal_cdoxidesum 303. pdf. Assessed February 2010

Ezaki T, Tsukahara T, Moriguchi J, Furuki K, Fukui Y, Ukai H, Okamoto S, Sakurai H, Honda S, Ikeda M (2003) Analysis for threshold levels of cadmium in urine that induce tubular dysfunction among women in non-polluted areas in Japan. Int Arch Occup Environ Health 76: 197-204

Flanagan PR, McLellan JS, Haist J, Cherian G, Chamberlain MJ, Valberg LS (1978) Increased dietary cadmium absorption in mice and human subjects with iron deficiency. Gastroenterology 74:841-846

Gallagher CM, Kovach JS, Meliker JR (2008) Urinary cadmium and osteoporosis in U.S. Women $\geq 50$ years of age: NHANES 1988-1994 and 1999-2004. Environ Health Perspect 116:1338-1343

Gennart JP, Buchet JP, Roels H, Ghyselen P, Ceulemans E, Lauwerys R (1992) Fertility of male workers exposed to cadmium, lead, or manganese. Am J Epidemiol 135: 1208-1219

Grondin MA, Ruivard M, Perreve A, Derumeaux-Burel H, Perthus I, Roblin J, Thiollieres F, Gerbaud L (2008) Prevalence of iron deficiency and health-related quality of life among female students. J Am Coll Nutr 27:337-341

Hartwig A (2010) Mechanisms in cadmium-induced carcinogenicity: recent insights. Biometals. doi:10.1007/s10534010-9330-4

Haswell-Elkins M, Satarug S, O'Rourke P, Moore M, Ng J, McGrath V, Walmby M (2008) Striking association between urinary cadmium level and albuminuria among Torres Strait Islander people with diabetes. Environ Res 106:379-383

Hill AB (1965) The environment and disease: association or causation? Proc R Soc Med 58:295-300

Hogervorst J, Plusquin M, Vangronsveld J, Nawrot T, Cuypers A, Van HE, Roels HA, Carleer R, Staessen JA (2007) House dust as possible route of environmental exposure to cadmium and lead in the adult general population. Environ Res 103:30-37

Honda R, Tsuritani I, Noborisaka Y, Suzuki H, Ishizaki M, Yamada Y (2003) Urinary cadmium excretion is correlated with calcaneal bone mass in Japanese women living in an urban area. Environ Res 91:63-70

Järup L, Alfvén T (2004) Low level cadmium exposure, renal and bone effects-the OSCAR study. Biometals 17: 505-509 
Järup L, Alfvén T, Persson B, Toss G, Elinder CG (1998a) Cadmium may be a risk factor for osteoporosis. Occup Environ Med 55:435-439

Järup L, Bellander T, Hogstedt C, Spang G (1998b) Mortality and cancer incidence in Swedish battery workers exposed to cadmium and nickel. Occup Environ Med 55:755-759

Järup L, Berglund M, Elinder CG, Nordberg G, Vahter M (1998c) Health effects of cadmium exposure-a review of the literature and a risk estimate. Scand J Work Environ Health 24(Suppl 1):1-51

Jaworowski Z, Barbalat F, Blain C, Peyre E (1985) Heavy metals in human and animal bones from ancient and contemporary France. Sci Total Environ 43:103-126

Jin YH, Clark AB, Slebos RJ, Al-Refai H, Taylor JA, Kunkel TA, Resnick MA, Gordenin DA (2003) Cadmium is a mutagen that acts by inhibiting mismatch repair. Nat Genet 34:326-329

Jin T, Nordberg G, Ye T, Bo M, Wang H, Zhu G, Kong Q, Bernard A (2004) Osteoporosis and renal dysfunction in a general population exposed to cadmium in China. Environ Res 96:353-359

Kazantzis G, Blanks RG, Sullivan KR (1992) Is cadmium a human carcinogen? IARC Sci Publ 118:435-446

Kellen E, Zeegers MP, Hond ED, Buntinx F (2007) Blood cadmium may be associated with bladder carcinogenesis: the Belgian case-control study on bladder cancer. Cancer Detect Prev 31:77-82

Kippler M, Goessler W, Nermell B, Ekstrom EC, Lonnerdal B, El AS, Vahter M (2009) Factors influencing intestinal cadmium uptake in pregnant Bangladeshi women-a prospective cohort study. Environ Res 109:914-921

Kobayashi E, Suwazono Y, Honda R, Dochi M, Nishijo M, Kido T, Nakagawa H (2008) Changes in renal tubular and glomerular functions and biological acid-base balance after soil replacement in Cd-polluted rice paddies calculated with a general linear mixed model. Biol Trace Elem Res 124:164-172

Kriegel AM, Soliman AS, Zhang Q, El-Ghawalby N, Ezzat F, Soultan A, bdel-Wahab M, Fathy O, Ebidi G, Bassiouni N, Hamilton SR, Abbruzzese JL, Lacey MR, Blake DA (2006) Serum cadmium levels in pancreatic cancer patients from the East Nile Delta region of Egypt. Environ Health Perspect 114:113-119

Kurihara I, Kobayashi E, Suwazono Y, Uetani M, Inaba T, Oishiz M, Kido T, Nakagawa H, Nogawa K (2004) Association between exposure to cadmium and blood pressure in Japanese peoples. Arch Environ Health 59:711-716

McElroy JA, Shafer MM, Trentham-Dietz A, Hampton JM, Newcomb PA (2006) Cadmium exposure and breast cancer risk. J Natl Cancer Inst 98:869-873

Menke A, Muntner P, Silbergeld EK, Platz EA, Guallar E (2009) Cadmium levels in urine and mortality among U.S. adults. Environ Health Perspect 117:190-196

Messner B, Bernhard D (2010) Cadmium and cardiovascular diseases: cell biology, pathophysiology, and epidemiological relevance. Biometals. doi:10.1007/s10534-0109314-4

Messner B, Knoflach M, Seubert A, Ritsch A, Pfaller K, Henderson B, Shen YH, Zeller I, Willeit J, Laufer G, Wick G, Kiechl S, Bernhard D (2009) Cadmium is a novel and independent risk factor for early atherosclerosis mechanisms and in vivo relevance. Arterioscler Thromb Vasc Biol 29:1392-1398

Nakagawa H, Nishijo M (1996) Environmental cadmium exposure, hypertension and cardiovascular risk. J Cardiovasc Risk 3:11-17

Navas-Acien A, Selvin E, Sharrett AR, Calderon-Aranda E, Silbergeld E, Guallar E (2004) Lead, cadmium, smoking, and increased risk of peripheral arterial disease. Circulation 109:3196-3201

Navas-Acien A, Silbergeld EK, Sharrett R, Calderon-Aranda E, Selvin E, Guallar E (2005) Metals in urine and peripheral arterial disease. Environ Health Perspect 113:164-169

Navas-Acien A, Tellez-Plaza M, Guallar E, Muntner P, Silbergeld E, Jaar B, Weaver V (2009) Blood cadmium and lead and chronic kidney disease in US adults: a joint analysis. Am J Epidemiol 170:1156-1164

Nawrot T, Den HE, Thijs L, Staessen JA (2003) Isolated systolic hypertension and the risk of vascular disease. Curr Hypertens Rep 5:372-379

Nawrot T, Plusquin M, Hogervorst J, Roels HA, Celis H, Thijs L, Vangronsveld J, Van HE, Staessen JA (2006) Environmental exposure to cadmium and risk of cancer: a prospective population-based study. Lancet Oncol 7:119-126

Nawrot TS, Van HE, Thijs L, Richart T, Kuznetsova T, Jin Y, Vangronsveld J, Roels HA, Staessen JA (2008) Cadmiumrelated mortality and long-term secular trends in the cadmium body burden of an environmentally exposed population. Environ Health Perspect 116:1620-1628

Nawrot TS, Kuenzli N, Sunyer J, Shi TM, Moreno T, Viana M, Heinrich J, Forsberg B, Kelly FJ, Sughis M, Nemery B, Borm P (2009) Oxidative properties of ambient PM2.5 and elemental composition: heterogeneous associations in 19 European cities. Atmos Environ 43:4595-4602

Nawrot T, Geusens P, Nulens T, Nemery B (2010). Occupational cadmium exposure, calcium excretion, bone density and risk for osteoporosis. J Bone Miner Res 25(6):14411445

Nishijo M, Tawara K, Honda R, Kuriwaki J, Nakagawa H, Tanebe K, Saito S (2004) Cadmium and nutritional intake in pregnant Japanese women. Toxicol Lett 148:171-176

Nishijo M, Morikawa Y, Nakagawa H, Tawara K, Miura K, Kido T, Ikawa A, Kobayashi E, Nogawa K (2006) Causes of death and renal tubular dysfunction in residents exposed to cadmium in the environment. Occup Environ Med 63:545-550

Nordberg GF, Nogawa K, Nordberg M et al (2007) Cadmium. In: Nordberg GF, Fowler BF, Nordberg $\mathrm{M}$ et al (eds) Handbook on the toxicology of metals. Elsevier, Amsterdam, pp 445-486

Olsson IM, Bensryd I, Lundh T, Ottosson H, Skerfving S, Oskarsson A (2002) Cadmium in blood and urineimpact of sex, age, dietary intake, iron status, and former smoking-association of renal effects. Environ Health Perspect 110:1185-1190

Plusquin M, Nawrot TS, Staessen JA (2005) Peripheral arterial disease and metals in urine and blood. Environ Health Perspect 113:A510-A511

Resnick HE, Lindsay RS, McDermott MM, Devereux RB, Jones KL, Fabsitz RR, Howard BV (2004) Relationship of 
high and low ankle brachial index to all-cause and cardiovascular disease mortality: the Strong Heart Study. Circulation 109:733-739

Roels HA, Roels HA, Hoet P, Lison D (1999) Usefulness of biomarkers of exposure to inorganic mercury, lead, or cadmium in controlling occupational and environmental risks of nephrotoxicity. Ren Fail 21:251-262

Satarug S, Nishijo M, Ujjin P, Vanavanitkun Y, Moore MR (2005) Cadmium-induced nephropathy in the development of high blood pressure. Toxicol Lett 157:57-68

Schutte R, Nawrot T, Richart T, Thijs L, Roels HA, Van Bortel LM, Struijker-Boudier H, Staessen JA (2008a) Arterial structure and function and environmental exposure to cadmium. Occup Environ Med 65:412-419

Schutte R, Nawrot TS, Richart T, Thijs L, Vanderschueren D, Kuznetsova T, Van HE, Roels HA, Staessen JA (2008b) Bone resorption and environmental exposure to cadmium in women: a population study. Environ Health Perspect 116:777-783

Schwartz GG, Il'yasova D, Ivanova A (2003) Urinary cadmium, impaired fasting glucose, and diabetes in the NHANES III. Diabetes Care 26:468-470

Sorahan T, Lancashire RJ (1997) Lung cancer mortality in a cohort of workers employed at a cadmium recovery plant in the United States: an analysis with detailed job histories. Occup Environ Med 54:194-201

Sorahan T, Waterhouse JA (1983) Mortality study of nickelcadmium battery workers by the method of regression models in life tables. Br J Ind Med 40:293-300

Sorahan T, Lister A, Gilthorpe MS, Harrington JM (1995) Mortality of copper cadmium alloy workers with special reference to lung cancer and non-malignant diseases of the respiratory system, 1946-92. Occup Environ Med 52:804-812

Staessen JA, Lauwerys RR, Ide G, Roels HA, Vyncke G, Amery A (1994) Renal function and historical environmental cadmium pollution from zinc smelters. Lancet 343:1523-1527

Staessen JA, Roels HA, Emelianov D, Kuznetsova T, Thijs L, Vangronsveld J, Fagard R (1999) Environmental exposure to cadmium, forearm bone density, and risk of fractures: prospective population study. Public Health and Environmental Exposure to Cadmium (PheeCad) Study Group. Lancet 353:1140-1144

Staessen JA, Kuznetsova T, Roels HA, Emelianov D, Fagard R (2000) Exposure to cadmium and conventional and ambulatory blood pressures in a prospective population study. Public Health and Environmental Exposure to Cadmium Study Group. Am J Hypertens 13:146-156

Staessen JA, Nawrot T, Hond ED, Thijs L, Fagard R, Hoppenbrouwers K, Koppen G, Nelen V, Schoeters G, Vanderschueren D, Van HE, Verschaeve L, Vlietinck R, Roels HA (2001) Renal function, cytogenetic measurements, and sexual development in adolescents in relation to environmental pollutants: a feasibility study of biomarkers. Lancet 357:1660-1669

Tellez-Plaza M, Navas-Acien A, Crainiceanu CM, Guallar E (2008) Cadmium exposure and hypertension in the 19992004 National Health and Nutrition Examination Survey (NHANES). Environ Health Perspect 116:51-56

Vahter M, Åkesson A, Liden C, Ceccatelli S, Berglund M (2007) Gender differences in the disposition and toxicity of metals. Environ Res 104:85-95

Van Der Klift M, Pols HA, Geleijnse JM, Van Der Kuip DA, Hofman A, De Laet CE (2002) Bone mineral density and mortality in elderly men and women: the Rotterdam Study. Bone 30:643-648

van Wijngaarden, Singer EA, Palapattu GS (2008) Prostatespecific antigen levels in relation to cadmium exposure and zinc intake: results from the 2001-2002 National Health and Nutrition Examination Survey. Prostate 68:122-128

Verougstraete V, Lison D, Hotz P (2003) Cadmium, lung and prostate cancer: a systematic review of recent epidemiological data. J Toxicol Environ Health B Crit Rev 6:227255

Vinceti M, Venturelli M, Sighinolfi C, Trerotoli P, Bonvicini F, Ferrari A, Bianchi G, Serio G, Bergomi M, Vivoli G (2007) Case-control study of toenail cadmium and prostate cancer risk in Italy. Sci Total Environ 373:77-81

Wang H, Zhu G, Shi Y, Weng S, Jin T, Kong Q, Nordberg GF (2003) Influence of environmental cadmium exposure on forearm bone density. J Bone Miner Res 18:553-560

Watkin RD, Nawrot T, Potts RJ, Hart BA (2003) Mechanisms regulating the cadmium-mediated suppression of Sp1 transcription factor activity in alveolar epithelial cells. Toxicology 184:157-178

Yiin LM, Rhoads GG, Rich DQ, Zhang J, Bai Z, Adgate JL, Ashley PJ, Lioy PJ (2002) Comparison of techniques to reduce residential lead dust on carpet and upholstery: the New Jersey assessment of cleaning techniques trial. Environ Health Perspect 110:1233-1237

Zhu G, Wang H, Shi Y, Weng S, Jin T, Kong Q, Nordberg GF (2004) Environmental cadmium exposure and forearm bone density. Biometals 17:499-503 